\title{
Property in Human Biomaterials: A New Methodology
}

Abstract: In disputes over the use and possession of the human body and its parts there has been a marked reliance on property law concepts. Judges frequently resort to the language of 'ownership', 'gifts', 'donations', 'trusts' and so on, in order to resolve disputes over the use of human biomaterials. When this happens, however, we observe certain recurring mistakes. Judges and academics writing in this area have sometimes misunderstood the basic rules governing the creation and operation of property rights. We do not seek to take a stance on the normative matters at stake. Our aim is to provide an accurate account of how property law could operate when applied in the context of human tissue use. We hope to redress some misconceptions, but our bigger goal is to provide a new methodology of how to work through the various questions that must be considered when determining how to regulate human tissue, and explaining how property principles would work at each stage. In this way, we seek to enable those who wish to debate whether property principles should be applied to human tissue the means to have accurate debates.

Keywords: property, human tissue, biomaterials, ownership

Word count: 13676 (incl. footnotes) 


\section{PROPERTY IN HUMAN \\ BIOMATERIALS: A NEW \\ METHODOLOGY}

In disputes over the use and possession of the human body and its parts there has been a marked reliance on property law concepts. Judges frequently resort to the language of 'ownership', 'gifts', ‘donations', 'trusts' and so on, in order to resolve disputes over the use of human biomaterials. What is interesting about this line of cases is that the language of 'property' is not being invoked as a mere rhetorical device by the courts, but serves real doctrinal purposes, such as the unlocking of proprietary remedies and ways of conceptualising transactions. When this happens, however, we observe certain recurring mistakes. In particular, judges and academics writing in this area have sometimes misunderstood the basic rules governing the creation and operation of property rights. In one sense this is understandable. The legal status of human biomaterials presents great ethical challenges for lawmakers, and the complexities of property law may be the least of an adjudicator's worries. Yet if courts and commentators are to rely on the language of 'property' in order to justify a particular outcome, then it is important that this is done in a way that is consistent with the established rules and doctrines of property law.

In this paper, we do not seek to take a stance on the normative matters at stake, or at least only insofar as we point out some positions that are demonstrably weak given the state of the law. Our aim is to provide an accurate account of how property law could operate when applied in the context of human tissue use. We hope to redress some misconceptions, but our bigger goal is to provide a new methodology, if you will, of how to work through the various questions that must be considered when determining how to regulate human tissue, and explaining how property principles would work at each stage. In this way, we seek to enable those who wish to debate whether property principles should be applied to human tissue the means to have accurate debates. 


\section{THREE PROBLEMS}

It will be helpful to begin with a core case: let us say that a person, $\mathrm{A}$, undergoes some medical procedure, during which B excises some material, a tissue sample, from A's body. Let us say that B subsequently makes some use of the tissue sample, such as for the purpose of (profitable) scientific research, which was not authorised by A. Many of the cases in this field of law involve these basic facts, or a variation thereof. A question that arises is whether the law of property offers the means of resolving the dispute between A and B. Traditionally property law has not played this role as it has long been reluctant to recognise property rights in human biomaterials. ${ }^{1}$ The clearest expression of its hesitancy was the well-established rule that it was not possible to own a corpse. ${ }^{2}$ However, this stance is being gradually eroded by a series of cases that have drawn upon the principles of property law in order to resolve such disputes. The process began in the early 20th century when the English and Australian courts recognising that a person who had lawfully altered a corpse or parts through the application of work and skill could gain a right to possession of it. ${ }^{3}$ More recent cases have moved away from the 'work and skill' exception, and have shown greater willingness to recognise property rights in different forms of human bio-materials. Yet, as we will see, the rules governing the operation of property rights have often been ignored, misunderstood, or misapplied in these cases. We aim to highlight three such misunderstandings. The first relates to a tendency to ignore the rules governing the allocation of property rights. The second is concerned with unwarranted assumptions made when relying of the notion of a disposition of a property right. The third concerns assumptions frequently made regarding the content of property rights, in particular the apparent 'use rights' of an owner.

\footnotetext{
${ }^{1}$ See variously Haynes' case [1614] 77 ER 1389; $R$ v Kelly [1999] 2 WLR 384; Yearworth v North Bristol NHS Trust (2009) 3 WLR 118 (CA);. For an overview of the development of this stance in common law, see I. Goold, 'Why does it matter how we regulate the use of human body parts?' (2014) 40 JME 3.

${ }^{2}$ Doodeward v Spence (1908) 6 CLR 406; Dobson v North Tyneside Health Authority [1996] 4 All ER 474; $R$ v Kelly [1999] 2 WLR 384; Re Organ Retention Group Litigation QB.

${ }^{3}$ This position emerged originally in the Australian High Court decision in Doodeward $v$ Spence (1908) 6 CLR 40, and was later accepted in England and Wales in $R v$ Kelly [1999] 2 WLR 384; $A B v$ Leeds Teaching Hospital NHS Trust (2004) EWHC 644 (QB) and Dobson v North Tyneside Health Authority [1996] 4 All ER 474.
} 


\section{A. Allocation of rights}

In our core case - where A brings a claim against B for B's unauthorised use of a tissue sample - the argument that may be made by A is that B, by his conduct, has 'infringed A's property right'. In order for this argument to be successful, it should be incumbent upon A to establish that he actually holds (or held) such a right; unless he can do this, he cannot plead that B has infringed 'A's right'. Consequently, one of the first steps in the litigation between $\mathrm{A}$ and $\mathrm{B}$ should be the determination of the question: did A hold a property right in the tissue at the time of B's interference? In order to answer this question the law has developed a number of rules governing the creation and allocation of property rights. The default rule, which provides the starting point in all questions of allocation in property law, is the possession rule. According to this rule, whenever there is an ownerless thing, or res nullius, a property right in the thing is acquired by the person who takes possession of it. This can be seen in cases involving wild animals where a property right is allocated to the person who catches the animal, and hence takes possession of it, rather than the person who has, for instance, chased the animal and worn it down. Although this rule can be displaced by more appropriate rules of acquisition in particular cases, the rule is wideranging in its application, due to the fact that it applies not just to ownerless things but, via the operation of the doctrine of relative title, also to things belonging to others. ${ }^{4}$ Therefore it may be thought that this would provide the starting point when it comes to human biomaterials. These rules tell us in whom a property right in the material would vest, i.e. whether the right would vest in A or B (or some third person, $\mathrm{X})$. Determination of this issue should be a decisive stage in the litigation.

Despite this, the rules governing the allocation of property rights have been frequently ignored by the courts when dealing with cases in which property rights to human tissue have been asserted. A good example is the case of Yearworth $v$ North Bristol NHS Trust. ${ }^{5}$ In Yearworth the six claimants, before undergoing cancer treatment that could affect their fertility, gave sperm samples to the defendant hospital for safekeeping. The samples were frozen but the defendant carelessly allowed them to thaw. Five of the six men claimed for psychiatric injuries they alleged were

\footnotetext{
${ }^{4}$ Armory v Delamirie 93.

5 [2009] EWCA Civ 37.
} 
suffered as a result of learning that their sperm had been destroyed, potentially leaving them infertile. ${ }^{6}$ Because the damage could not be considered personal injury, the court had to consider whether the claimant's psychiatric loss was consequent upon any property damage. ${ }^{7}$

In light of the common law's traditional reluctance to recognise property rights in respect of such material, the question which occupied the court most was: 'can sperm form the subject matter of a property right?' In an important decision the Court of Appeal held that it could. Lord Judge CJ expressed dissatisfaction with the long standing exclusion of human tissue from the scope of property law, noting that developments in medical science had led to the need for a '.. re-analysis of the common law's treatment of and approach to the issue of ownership of parts or products of a living human body ... ${ }^{8}$ Having found that the sperm could be 'owned', the Court of Appeal held that the defendant was liable to the claimant for the negligent damage to the sperm (as a breach of the terms of the bailment under which it was transferred to the defendant).

There was, however, a missing step in court's reasoning. Whilst the court answered the question - 'can sperm form the subject matter of a property right?' - in the affirmative, it did not ask the question which logically follows: 'to whom should such a right be allocated?' Instead of asking this question, the court simply assumed that if it were to recognise a property right in the sperm, then the right would be held by the source of the material, the claimant. The default rule of acquisition, as noted above, in such cases (where the thing is res nullius) is that a property right in the thing will be acquired by the person who takes first possession of it. On the facts described in the judgment, it is not entirely clear which party this rule would favour, as this question was simply not considered to be relevant. However, it is, at the very least, possible that it could have been an employee of the hospital who was the first to meaningfully possess the sperm sample. If this happened, then according to the default rule of acquisition, any property rights would vest in the defendant, not the claimant, thus defeating the claim in negligence.

\footnotetext{
${ }^{6}$ The sixth claimed only for mental distress.

${ }^{7}$ No contractual claim could be brought as the sperm was stored by an NHS Trust, with whom no contracted had been made.

${ }^{8}$ Yearworth v North Bristol NHS Trust (2009) 3 WLR 118 (CA) [45](a).
} 
The court did not consider the standard rules of acquisition. Instead, it focused on the fact that under the Human Fertilisation and Embryology Act $1990^{9}$ the men had the right to prevent the hospital from using the sperm if they objected. This, the court opined, was consistent with the academic account of ownership proposed by Tony Honoré from 1961, in which he identified the 'indicia' of ownership, including a right to possess and a liberty to use. Unfortunately this reasoning is rather circular, in that the men would have held these indicia of ownership if the Act vested property rights in them' yet the Act is not a vesting statute. It does not, for instance, purport to confer on the men the right to sue third parties for unauthorised interferences or damage to the sperm (which is the hallmark of a property right - see below). These issues were not probed, and the court focused on the question of whether sperm could form the subject matter of a property right. Having answered that question in the affirmative ${ }^{10}$, the court simply presumed that the right was allocated to men. In taking this approach, the Court conflated the question of the property status of the sperm with the question of in whom rights to that sperm would vest, and consequently sidestepped the established rules of acquisition of property rights.

This is not to say that the outcome in Yearworth is necessarily the wrong one. Had the court been of the view that, in light of the policy behind the Human Fertilisation and Embryology Act 1990, it would be appropriate that the source of the sperm should always acquire the property rights, rather than the first possessor, then the rules of acquisition are flexible enough to accommodate this. There are a number of specific contexts in which the default possession rule is displaced by what is thought to be a more appropriate rule. ${ }^{11}$ In Yearworth the court could have made clear that the first possessor rule should give way to a different rule - that excision or separation of human tissue vests the right in the progenitor. Such an approach would have been not dissimilar from the rule that vests title to offspring of animal in owner of the mother. ${ }^{12}$ In other words, the court could still have reached the same conclusion in the case (that the claimant should succeed in his claim for negligent damage)

\footnotetext{
${ }^{9}$ Ibid [45](f).

${ }^{10}$ This approach was seen as involving a break with the past reluctance to recognise property rights at all, subject to the limited work and skill exception: ibid [45](a)-(e). In particular, it stated 'we are not content to see the common law in this area founded upon the principle in Doodeward': ibid [45](d).

${ }^{11}$ For example, the doctrine of specificatio and the rules in relation to treasure. These are discussed further below.

${ }^{12}$ Tucker v Farm \& General Investment Trust Ltd [1966] 2 All ER 508.
} 
simply by stating a rule of acquisition that favoured the men. As it happened, however, the issue was simply ignored.

A similar problem can be seen in one of the leading US decisions, Moore $v$ Regents of University of California. ${ }^{13}$ The claimant had consented to providing blood and tissue samples to the defendants for the purposes of cancer treatment. When the claimant discovered that the defendants had developed an extremely valuable cell line from the tissue samples, he brought a claim in, amongst other things, conversion for the infringement of his property rights. Rejecting the conversion claim, the court was reluctant to recognise that the cells could be made the subject of a property right. The principal reason for this was given by Panelli J:

[The] important policy consideration is that we not threaten with disabling civil liability innocent parties who are engaged in socially useful activities, such as researchers who have no reason to believe that their use of a particular cell sample is, or may be, against a donor's wishes. ${ }^{14}$

If the court were to recognise the existence of property rights in the excised cells, Panelli J reasoned, then this would allow the source of the material to prevent the University from carrying out valuable research on this type of material, or at least force the University to pay for the right to use the material. In order to prevent this, the court refused to recognise the existence of property rights in the excised cells. Here, then, the California Supreme Court made the same presumption about allocation as the Court of Appeal in Yearworth, and similarly subsumed the allocation question into the question of the legal status of the material. The problem with the decision in Moore, as in Yearworth, is that it is based upon the assumption that if property rights are recognised, then they would automatically be allocated to the source of the material. As explained above, there is no basis for this assumption. The default rule, that a property right is allocated to the first possessor, would favour the defendant, as it was the researchers who had excised the claimant's spleen and would thereby gain any property rights in it. This would have caused Panelli J's concerns to

\footnotetext{
${ }^{13}$ Moore v Regents of University of California (1990) 51 Cal 3d 120.

14 ibid 51.
} 
fall away, as far from hampering the defendant's research activities, property rights would have positively facilitated them. ${ }^{15}$

The Yearworth decision will arguably be the most influential precedent for future determinations of the property status of human tissue in England and Wales. It has already had an impact in Australia in a number of important cases. ${ }^{16}$ This is concerning given the problems identified here, as the decision sets a precedent for (wrongly) presuming that the question of in whom property rights vest is answered by determining only whether they will vest at all.

The implications of this mis-step are compounded by the tendency to make a similar conflation by legal scholars. Very often in the academic debate around the ownership of human tissue, commentators merge the question of whether human tissue can be the subject of a property right (the 'status question') with the question of to whom should such a right be allocated ('the allocation question'). Many make the assumption that if tissue can be the subject of a property right then the source will be the initial owner, and this then sets the starting for their analysis. This unsound foundation has skewed the debate in a number of problematic ways. For example, as Herring and Chau's note, there is often the view in relation to Moore that the case

shows the problem with not adopting the property approach. Vast sums of money were made by the scientists, but the person who made 'everything possible' was left with nothing. A property approach would ensure that he was adequately rewarded. ${ }^{17}$

According to this argument, the court in Moore should have recognised property rights in the excised cells as this would have had the effect of furnishing the claimant, as progenitor, with some financial reward. Herring and Chau, amongst others, reject a regarding human tissue as property for precisely the same reason --- that doing so allows the source to control what is done with the tissue to too great an extent. In their view, resisting treating tissue as property is a way to prevent individuals gaining too

\footnotetext{
${ }^{15}$ Mosk J (dissenting) took the view that such conversion claims would usually be defeated by the consent to donation given by the source individual.

${ }^{16}$ Bazley v Wesley Monash IVF [2010] QSC 118; Jocelyn Edwards; Re the estate of the late Mark Edwards [2011] NSWSC 478.

${ }^{17}$ J Herring and P Chau, 'My Body, Your Body and Our Bodies' [2007] Med LR 34, 53.
} 
much control over tissue, which would be better regarded as a community resource. ${ }^{18}$ Jasper Bovenberg takes a slightly different view, largely in line with the view of the majority in Moore. He suggests that if property rights were recognised then it would be profoundly difficult to establish useful biobanks for research. Such efforts would be hampered by 'costly transactions to acquire those rights, preceded by countless negotiations about the terms of the collection, storage and use of the samples'. ${ }^{19}$ Yet these normative arguments for and against the recognition of property rights in human tissues presume that any such rights would automatically be allocated to the source of the material. There is no basis for this assumption in the law of property and, once this is recognized, many of these arguments lose their normative force.

It is important to note that not every decision or academic commentary can be criticized on these grounds. Happily, there are certain decisions that do keep the status question separate from the allocation question. An example is the well-known case of Doodeward $v$ Spence, which established the 'work and skill' exception to the 'no property in a corpse' rule. The claimant in the case had preserved conjoined twins in spirits, and claimed that the defendant, a policeman, committed conversion when he seized them. The claim in Doodeward succeeded as the court held that when human tissue is the subject of 'work and skill' in order to preserve it then it can form the subject matter of a property right. Vitally, the court also made clear that it was the application of this work and skill by the claimant that led to his acquisition of the property right. This fits neatly with the specificatio principle, whereby a right in a newly manufactured thing is allocated to the person who has created the thing by their efforts. The status of Doodeward $v$ Spence is uncertain following the Yearworth case, but the methodology of the court's reasoning in the case still serves as an example because the court adopted a clear rule for the allocation of property rights: when human tissue is preserved, a right is allocated to the person who preserved by their skill and effort. In Doodeward, therefore, the status of the human tissue was

\footnotetext{
18 ibid 54-55.

${ }^{19} \mathrm{~J}$ Bovenberg 'Inalienably Yours? The New Case for an Inalienable Property Right in Human Biological Material: Empowerment of Sample Donors or a Recipe for a Tragic Anti-commons?’ (2004) 1 SCRIPT-ed 591, 575. See also Skene's suggestion that the allocation of property rights to source individuals would have a deleterious impact on hospital and research practices: L. Skene, 'Proprietary Rights in Human Bodies, Body Parts and Tissue: Regulatory Contexts and Proposals for New Laws' 22 Legal Studies 102, 107-8, 120.
} 
considered separately from the allocation question. It is unfortunate that this approach has not been followed in the more recent cases.

It is imperative that when the legal status of human tissues is debated the question of whether tissue should be owned must be kept separate from the question of who should own it. These are logically different questions that should be determined by different factors. In failing to recognise this, the arguments deployed by courts and commentators both for and against the recognition of property rights often lose their force. It has also, as we will see in the next section, led to unnecessary 'solutions' to work around the 'problem' of source-ownership. ${ }^{20}$

\section{B. Disposition of rights}

The concerns about chilling research expressed in Moore have played an important role in the debate over property rights and human biomaterials. As we saw, Panelli J's response to this concern was to refuse to recognise property rights in such material at all. Another common response is to invoke the notion of a 'disposition', whereby the source of the material is said to 'dispose' of any rights he holds in it, thus permitting another to use it.

One example of this approach can be found in the judicial reliance upon the notion of a transfer of property rights. Take our core case again, where A sues B for B's unauthorised use (for research purposes) of tissue excised from A's body. In order to prevent A from asserting a property right in the tissue sample which could restrict B's ability to use it in his research, it may be possible to invoke the notion of a transfer. Under this analysis, A is said to have 'transferred' his property rights in the material to B when he consensually underwent the medical procedure, making B's use entirely legal. An example of this analysis can be found in the US case of Washington University $v$ Catalona. ${ }^{21}$ The defendant was a university researcher, initially

\footnotetext{
${ }^{20}$ L. Skene, ‘Arguments against People Legally 'Owning’ Their Own Bodies, Body Parts and Tissue’ 2 Macquarie Law Journal 163, 147; L. Skene, 'Proprietary Interests in Human Bodily Material: Yearworth, Recent Australian Cases on Stored Semen and Their Implications' (2012) 20 Med LR 227, 242. See also C. Hawes, 'Property Interests in Body Parts: Yearworth v North Bristol NHS Trust' (2010) 73 MLR 130, 131; G. Dworkin and I. Kennedy, 'Human Tissue: Rights in the Body and its Parts’ 1 Medical LR 291, 303.

21490 F 3d 667 (2007).
} 
employed by the claimant university, who had been involved in the collection of tissue samples over a number of years. The dispute arose when the defendant was appointed to a new university and he wished to take the tissue samples with him, something that the claimant resisted. In finding that the claimant had title to the material, the court, relying on the legal notion of a transfer, held that when the tissue samples were excised from the donors, they had made a valid 'inter vivos gift' by voluntarily transferring them for no consideration to the claimant, thus transferring ownership. ${ }^{22}$ By transferring their property rights in the material to the claimant, the potential for donors to hinder research activities was curtailed as they had no legal basis upon which to restrain the claimant's use of the material.

A similar approach can be seen in the reliance on the doctrine of abandonment in certain contexts. According to this analysis, when a tissue sample is excised from A's body by B, A is said to 'abandon' his property right in the material, thus making it ownerless and permitting B's use of it. This analysis differs slightly from that of a 'transfer', as A's rights are not transferred to B; rather, A's rights are destroyed, rendering the tissue res nullius. This analysis was notably favoured by the Nuffield Council for Bioethics in their influential report, 'Human Tissue: Ethical and Legal Issues'. ${ }^{23}$ The council suggested that when human tissue is excised from a person, any subsequent use of the tissue in the course of medical research would be insulated from legal liability because the progenitor would have 'abandoned' his rights to it. ${ }^{24}$ For some, the possibility of abandonment means also that the next possessor can also gain a right to possession and then legitimately defend their possession (and protect their usage) against others. This is said to support the pursuit of medical research goals as it enables researchers to obtain and use discarded tissue in their work. For example, in presenting arguments for recognising property rights in biomaterials, which would vest in the individual from whom it was taken, Sophie Mills suggests that

\footnotetext{
22490 F 3d 667 (2007) [41].

${ }^{23}$ For criticism see: I Goold 'Abandonment and Human Tissue’ in I Goold and others (eds), Persons, Parts and Property: How Should We Regulate Human Tissue in the 21st Century? (Hart 2014), 125.

${ }^{24}$ The Nuffield Council on Bioethics recognised this in its 1995 report: Nuffield Council on Bioethics, Human Tissue: Ethical and Legal Issues (1995), para 9.13. See also Moore v Regents of University of California (1990) 51 Cal 3d 120, 144 per Panelli J.
} 
If a patient did not have strong opinions about the use of the tissue, the property status would facilitate a gift or abandonment of rights in it, and this would significantly clarify the legal ownership status of the tissue and help prevent and resolve any subsequent legal disputes. ${ }^{25}$

Although these concepts of 'transfer' and 'abandonment' may seem to explain why the source of a tissue sample could not restrain the subsequent use of the sample in scientific research, many problems arise at a doctrinal level. First, it is important to stress that when 'transfer' and 'abandonment' are used in the context of property law, they refer to the transfer and abandonment of rights, not the factual disposing of the thing. ${ }^{26}$ Both 'transfer' and 'abandonment', therefore, are concepts which presuppose that there are property rights to be disposed of. ${ }^{27}$ The problem here is that the common law, as noted, has traditionally been reluctant to recognise property rights in respect of human biomaterials, with a case such as Moore providing a clear example. It is, of course, open for a superior court, such as that in Catalona, to break with this approach and recognise property rights in respect of human biomaterials, as happened in Yearworth. However, in Catalona the issue was not addressed, with the court simply assuming that property rights in the material existed. The law's traditional reluctance to recognise such rights means that this assumption is difficult to sustain. The problem is, if anything, more striking with the Nuffield Council's reliance on abandonment. In their report the Nuffield Council argue at length that human tissue should not be made the subject matter of a property right, and advocate alternative regulatory schemes. The Council, therefore, has argued against property rights whilst invoking a doctrine, abandonment, which presupposes the existence of property rights.

If this first problem can be overcome, a second arises. Consider again our core case, where it may be argued that A has transferred his property rights in the tissue to $\mathrm{B}$ when he consented to undergo the operation. In order for it to be possible to say that A has either 'transferred' his right in the tissue sample to B, or abandoned his right to it, then not only must the law recognise a property right in respect of the

\footnotetext{
${ }^{25}$ S. Mills, 'Owning my 'self': a reconcilliation of perspectives on the body' (1999) 6 UCL Jurisprudence Review 191, 204.

${ }^{26}$ The legal device of a deed illustrates this easily --- the right to property in an item can be transferred by deed even though physical possession of that item is retained.

${ }^{27}$ See further R Nwabueze, 'Cadavers, Body Parts and the Remedial Problem' in Goold and others (eds), Persons, Parts and Property, 157 at $170 \mathrm{ff}$.
} 
tissue sample, it must also allocate it to A. This may be difficult to establish on the facts of a case. In Catalona, for instance, it was the defendant and his team of researchers who, having excised much the disputed material, who were the first to take possession and, hence, would normally acquire a property right in it before the source of the material could acquire such rights. If the normal acquisition rules were applied to the facts of Catalona, then it would seem highly unlikely that the donors of the material had any rights that they were capable of transferring or abandoning.

Further problems attend the doctrine of abandonment. In particular, the legal status of the doctrine is, at best, tenuous. The English law is deeply reluctant to recognise that an owner can destroy his title, and make the thing res nullius, by physically disposing of the thing. ${ }^{28}$ If the doctrine does exist, it will apply only in very limited situations where a clear intention to abandon can be identified. Therefore, the common academic view that tissue could be presumed abandoned where the source of tissue has no further interest in it, is unlikely to hold. ${ }^{29}$ In fact, there is particular resistance in the English case law at least to presuming abandonment. Quite the contrary, the courts tend to find abandonment only when there is strong evidence of an intention to do so ${ }^{30}$ This has serious implications for both courts and commentators, such as Mills, who seek to address problems with their property models via reference to a presumption of abandonment as claims about the likely legal outcomes where materials are discarded will be mistaken, and the asserted problems with the property model will not have been resolved.

\footnotetext{
${ }^{28}$ See, eg, A.S. Burrows, English Private Law (2nd ed., Oxford 2007) (WJ Swadling), [4.568]; I Goold 'Abandonment and Human Tissue' in Goold and others (eds), Persons, Parts and Property. For an excellent review of commonwealth authority, see E Hudson and R Burrell, 'Abandonment, Copyright and Orphaned Works: What Does it Mean to Take the Proprietary Nature of Intellectual Property Rights Seriously?’ (2011) 35 Melbourne LR 971, 974-982. Hudson and Burrell are more optimistic about the possibility of abandonment than the present authors.

${ }^{29}$ L. Skene, 'Ownership of Human Tissue and the Law' 3 Nature Reviews: Genetics 145, 147. G. Dworkin and I. Kennedy, 'Human Tissue' 1 Medical Law Review 291, 303. See also Lori Andrews’ view that 'The courts in Moore and Greenberg could assume a gift was made, or that the tissue was abandoned, because there was no document reserving any rights on the part of the patients': L. Andrews, 'Who Owns Your Body? A Patient's Perspective on Washington University v Catalona' 34 Journal of Law, Medicine and Ethics 398-407, 400. It should be noted that Skene is writing in the Australian context, where the threshold for finding something has been abandoned is arguably lower, but it is still highly contestable that a mere failure to claim a future interest in one's property amounts to abandonment (I. Goold 'Abandonment and Human Tissue' in Goold and others (eds), Persons, Parts and Property, 125).

${ }^{30}$ Goold ‘Abandonment and Human Tissue’, $130 \mathrm{ff}$.
} 


\section{Content of rights}

A further misconception which has distorted the debate over the legal status of human biomaterials is the view that a property approach would lead to the commercialization of such materials. To allocate a property right in such material to a particular person, according to this argument, would be to give that person the legal right to exploit the material commercially, something which is often seen as undesirable. Thomas Murray asserts that

putting a price on the priceless, even a high price, and actually cheapens it. So we don't approve of selling out body parts; and the body isn’t quite property. ${ }^{31}$

But in fact commercialization and exploitation are not inevitable consequences of the recognition of property rights. The law of property is neutral to the issue of exploitation: it neither protects an owner's right to use a thing, nor restricts his ability to do so. Consequently, the concerns explored by many commentators about the potential to exploit human biomaterials will arise irrespective of whether or not property rights are recognised. ${ }^{32}$ To make this point we need to say something about the content of property rights.

A property right is identified by the enforceability of the right, with such rights typically said to be 'enforceable against the world'. Take the example of a clear property right, freehold title to land ('ownership' of land, in lay terms). If a person, A, has freehold title to a plot of land, and B, without permission, crosses A's plot of land, then B can be liable for this trespass. However, the same is true if C, D, E or F etc walk across A's land without permission: they will all equally be liable for trespass. The point is that A's right is labelled a 'property right' because he is owed a duty by all persons. The important issue, and the one which is relevant to the concern raised

\footnotetext{
${ }^{31}$ T.H. Murray, 'The Gift of Life Must Always Remain a Gift' (March) Discover 90, 90. See also Herring and Chau, 'My Body, Your Body and Our Bodies', 42; CH Harrison, 'Neither Moore nor the Market: Alternative Models for Compensating Contributors of Human Tissue'(2002) 28 Am J L Med 77, 89; SR Munzer, ‘An Uneasy Case Against Property Rights in Body Parts’ (1994) 11 Soc Phil Policy 259, 286; C. Banwell, 'Should I have Property in my Body?' (1994) UCL Jurisprudence Review, 1.

${ }^{32}$ On concerns about commercialization and its relationship to propertization (on which there is a wide spectrum of views), see, eg, C. Banwell, 'Should I have Property in my Body?'; J R Karlsen et al, “To know the value of everything - a critical commentary on B Bjorkman and S O Hansson's “Bodily rights and property rights”’ (2006) JME 32;215-219, 2168; L.B. Andrews, ‘My Body, My Property’ 16 Hastings Center Report 28.
} 
by Herring et al, is the content of this duty: if A has title to a tissue sample, for example, what types of behaviour must B, C, D etc refrain from engaging in? It is this question that may prove decisive for those making normative arguments about the appropriateness of a property law system regulating human biomaterials. The more onerous the duties owed to the owner of biomaterials, the more uneasy some become with the notion.

There are some observations on the content of property rights that we can make with a reasonable degree of confidence. The first observation is that the holder of a property right is almost certainly owed a duty of non-interference by others. This is sometimes called a 'right of exclusion'. This can be readily inferred from the law of torts, especially torts such as trespass, conversion and negligence. Should A, for instance, have a property right in respect of a car, and B (or C or D etc) causes some physical interference with the car, such as by scratching it, denting it, smashing a window etc, then he will be in breach of duty and liable in one of these torts. From this basic observation we can say that persons generally owe the holder of a property right a duty to refrain from physically interfering with the thing. Accordingly, in our core case, to allocate a property right, for example, to A, is to say that all others (including B) owe A a duty to refrain from physically interfering with the material.

That property rights entail rights of non-interference is not controversial. The more difficult question, which relates directly to concerns about property enabling objectionable uses of tissue, is whether property rights also consist of 'use rights'. It is often said that an owner of a thing has a 'right to use' the thing. ${ }^{33}$ The apparent 'right to use' explains, to an extent, why there are concerns that a property approach would enable the commercialisation of human biomaterials. According to this view, if the law were to allocate property rights in a tissue sample to a person, A, then A's ability to exploit the material for commercial purposes would be directly protected by the law as he would have a 'right to use' it.

The concern over property rights facilitating commercialization, we suggest, is misconceived because it is not correct to conceptualise property rights as including a

\footnotetext{
${ }^{33}$ This view is nearly ubiquitous in the literature around property in body parts, and can very often be traced to a misconception of Tony Honoré's work on the concept of ownership in A.M. Honoré, 'Ownership' in in A. Guest (ed) Oxford Essays in Jurisprudence (Oxford Clarendon Press 1961).
} 
'right to use'. The word 'right' is usually reserved for a legal relationship that imposes a duty upon another person to behave in a certain way. ${ }^{34}$ An owner's 'right of noninterference' is a 'right' properly so called because it imposes a legal duty upon others to behave in a certain way: a duty to refrain from physical interferences with the owner's thing. A 'right to use', on the other hand, does not impose a legal duty upon others to behave in a certain way. There is no legal duty to refrain from impairing an owner's ability to use his thing. ${ }^{35}$ The better word to describe the legal status of 'use' is that of 'liberty'. ${ }^{36}$ This nomenclature was favoured by Cave $\mathrm{J}$ in Allen $v$ Flood who stated:

it was said that a man has a perfect right to fire off a gun, when all that was meant, apparently, was that a man has a freedom or liberty to fire off a gun so long as he does not violate or infringe any one's rights in doing so .... ${ }^{37}$

To say that an owner of a thing has a 'liberty' to use his thing is simply to say that his use is permitted; he is under no legal duty to others not to use his thing and, in the absence of such a duty, his use is permitted. If A owns a car, then A is under no duty to others (B, C, D etc) not to use the car and, in the absence of such a duty, A's use is permitted.

To describe 'use' as a 'liberty', rather than a 'right', is significant. The reason for this is that a 'liberty to use', as described, would exist irrespective of whether or not property rights were recognised to exist in respect of human biomaterials. Let us say that a person, $\mathrm{A}$, is in possession of a tissue sample. Let us also say that a court refuses to recognise that $\mathrm{A}$, or anyone else, is capable of holding a property right in respect of the blood sample, so that it is res nullius. It would still be case that A would not owe any other person (B, C, D etc) a duty not to use the blood sample. If A started, for instance, to use the tissue sample in the course of medical research, he would not thereby incur liability to B, C or D etc, as he would have breached no duty

\footnotetext{
${ }^{34}$ W. Hohfeld, 'Some Fundamental Legal Conceptions as Applied in Judicial Reasoning’ 26 Yale Law Journal 16.

${ }^{35}$ D Pride \& Partners (A Firm) v Institute for Animal Health [2009] EWHC 685 (QB); Club Cruise Entertainment \& Travelling Services Europe BV v Department for Transport (The Van Gogh) [2008] EWHC 2794 (Comm).

${ }^{36}$ Hohfeld, 'Some Fundamental Legal Conceptions’, 38.

${ }^{37}$ [1898] AC 1, 29. Further, note: 'Evidence of [the fact that a 'right to use' is not a crucial element of ownership] can be found in the numerous examples of statutes that have deprived owners of liberties to use their things without depriving them of ownership: S Douglas, 'Property Rights in Human Biological Material’ in Goold and others (eds), Persons, Parts and Property, 103.
} 
in so doing. This means that A would still have a liberty to use the tissue sample: his use would be legally permitted as against other people. ${ }^{38}$ As a liberty to use exists irrespective of whether or not a court recognises property rights in respect of the tissue sample, it cannot be said that property law is directly facilitating the commercial use of human biomaterials. Rather, it is neutral as to this issue in that it neither confers a 'right to use' nor restricts an owner's liberty to use. ${ }^{39}$ Consequently, whilst commercialization may be a legitimate concern, it would not be the product of property rights.

This neutrality has the added implication that the use of an item can be legally restricted regardless of any property rights that are held in it. For example, if A is the owner of a knife, and has the liberty to use it as he wishes, this does not mean that the law cannot restrict him from using that knife to stab someone. But the very same restriction applies to $B$ in relation to the knife --- he too may not use it stab someone. That $\mathrm{A}$ is the owner and $\mathrm{B}$ is not is irrelevant, the restriction on use has nothing to do with property rights. ${ }^{40}$

Concerns about commercial exploitation (so long as it is a valid concern) are far better dealt with by imposing statutory restrictions on the ways in which an owner of such material could use it than refusing to accord it the status of property. Imposing such restrictions is a fairly common practice with certain types of property rights. An example is the Town and Country Planning Act 1990, and a raft of other environmental legislation ${ }^{41}$, which provides that a freeholder who wishes to carry out building, engineering, mining or other operations in, on, under or over his land, must

\footnotetext{
${ }^{38}$ But note that B, C, D etc each have the same liberty.

${ }^{39}$ Although compare the view of Nwabueze, who suggests that there is a 'right to use' things, but that the existence of such a right does not in and of itself admit such things to the category of property': \{Nwabueze, 2010 \#574\}, 563-4.

${ }^{40}$ This is an example of a property-independent restriction. As James Harris pointed out in Property and Justice, 'The use-privileges inherent in full-blooded ownership never carry even prima facie exemption from property independent prohibitions. The recognition that I am prohibited from smashing windows with my hammer does not contradict my claim to be "full” owner of the hammer': J. Harris, Property and Justice (Oxford and New York 1996), 248. He also rightly notes elsewhere that 'claim-rights and duties are conferred or imposed by rules which presuppose ownership interests and are not, analytically, integral to ownership conceptions': ibid, 30. That said, there are small number of 'property-limitation rules' that do run with the ownership interest, such as duties not to use ones land such as to cause a nuisance: ibid, 34, but in the main, restrictions on use of property are not integral to the ownership of that property per se.

${ }^{41}$ See generally K Gray, 'Land Law and Human Rights’ in L Tee (ed), Land Law: Issues, Debate, Policy (Willan, Devon 2002).
} 
first apply to the relevant local authority for planning permission. ${ }^{42}$ In respect of human biomaterials, if similar policy concerns were expressed, then these could be more effectively met by similar legislation, not the denial of the existence of property rights. ${ }^{43}$

It is also worth noting that even if property rights in human tissue were denied, this would not necessarily prevent commercialisation. The existence, or not, of property rights does not determine whether in reality something is commercialisable. Tissue samples are regularly traded at present without any clear legal recognition that they are 'property'. Indeed, corpses and their parts have been bought and sold for centuries, despite the long-standing rule that a corpse could not be owned. In modern times, tissue samples can be purchased from commercial ventures who process and supply tissue for medical research. In the absence of clear property rights in samples it is not clear what, legally, is being transferred in a commercial transaction in relation to tissue, but it is certainly the case that tissue is actively traded at present despite its murky legal status. ${ }^{44}$

\section{Conclusion on misconceptions}

In making these criticisms, we may leave ourselves open to the criticism of being overly pedantic in our plea for the correct application of property law principles. Yet we feel that there are good reasons for pointing out the problems. Consider, for instance, the huge amount of biomaterials held by research institutions. A number of questions arise in respect of such material: is this material regulated by property law? If so, then to whom are property rights in this material allocated? Is it possible for such rights to be transferred or destroyed? What is the content of these rights? The basic rules of property law provide clear answers to these questions. By ignoring, or misapplying, them, the legal position becomes unclear, and a basic question - such as

\footnotetext{
42 Town and Country Planning Act 1990 s 57.

${ }^{43}$ This was, in fact, accepted in Yearworth.

44 The status of such tissue is unclear. It may be property in accordance with s.32(9) of the Human Tissue Act 2004, which essentially gives legislative form to the common law work and skill exception. However, given the limited interpretation of this exception take in Dobson $v$ North Tyneside Health Authority [1996] 4 All ER 474 and AB v Leeds Teaching Hospital NHS Trust [2004] EWHC 644 (QB), tissue samples sold for research may not fall within it. However, trade in it is probably permitted via s 32(6) of the same Act.
} 
'who owns that tissue sample?' - becomes very difficult to answer. It also becomes difficult to have a useful discussion of alternatives to property law because a comparison of outcomes cannot be made. Our aim in the next section is to provide a clear map of property law's basic doctrines that should allow those debating the issue to avoid some of the problems outlined here.

\section{A NEW METHODOLOGY}

In this section we set out a methodology for a court to follow in cases involving human biomaterials. If we take our core case - where a tissue sample is excised from A's body by B, and A brings a claim against B for B's unauthorised use of the sample - then we suggest that a court should consider the following questions:

1. Can the biomaterial form the subject matter of a property right?

2. Should the biomaterial form the subject matter of a property right?

3. To whom would the property right be allocated?

4. Would there be any defences to the property right?

We argue that if a court considers these questions, in this order, then it will help the court to escape the difficulties discussed above. It is important to stress that we do not aim to make any normative arguments about how or whether property law should regulate the use of human tissue in this section. Rather, we wish to provide a framework within which those who are making the normative arguments can do so.

\section{A. Can human biomaterial form the subject matter of a property right?}

As noted above, in our core case - where A sues B for B's unauthorised use of a tissue sample - the claim made by A may seek to drawn upon the law of property. A may argue that B, by his unauthorised use, has 'infringed A's property right in the tissue sample'. Should a court be confronted with such a claim, then we suggest that the very first question that it should consider is whether the material in question is capable of forming the subject matter of a property right.

As a basic principle, anything with a physical existence can be made the subject matter of a property right. In the opening passages of Book II of Gauis' 
Institutes, where the author deals with the scope and reach of the Roman law of property, we find the statement: 'Corporeal things are those which are tangible, as land, a slave, a garment, gold, silver, and, indeed, other things innumerable. ${ }^{45}$ The last word in this quote, 'innumerable', is telling. There would be little point in enumerating all of the different physical things that are capable of being owned, as the list is an open-ended one. As Ben McFarlane states, 'The presumption is that any physical object can be the subject of a property right ... ${ }^{46}$ Human biomaterials, whether they be blood or tissue samples, organs, excised cells or entire cadavers, have a physical existence and are as tangible as any car, coin, painting or piece of land. The starting point, therefore, should be that such material could be made the subject matter of a property right.

There is, however, an important qualification to this statement, and this is that this view relates only to corpses and to tissue that has been removed from the living body. It cannot apply to the living body itself, because at a doctrinal level, selfownership is an impossibility. The reason for this is that the rules which constitute the law of property become largely incoherent when applied to a person's own body. Principles such as that a person can acquire a property right via possession, or that rights may be transferred via delivery cannot sensibly be applied to living persons and hence living bodies must be governed by different rules. ${ }^{47}$ However, when we turn to human biomaterials that are separate from us, such as excised tissue samples, ejaculated sperm or hair clippings, we reach the opposite conclusion. These are things that can be possessed, delivered and disposed of. As such the rules governing the operation of property rights can be applied to these things.

When a court is faced with a dispute over human biomaterials and it seeks to draw upon property law principles, then the first question it must ask is whether the material in question can be made the subject matter of a property right. The criterion

\footnotetext{
45 ibid II.13.

${ }^{46}$ B McFarlane, The Structure of Property Law (Hart, Oxford, 2008), 137.

${ }^{47}$ Although compare the position taken by Muireann Quigley,' Property in Human BiomaterialsSeparating Persons and Things? (2012) 32 OJLS 659, 681-2. Several scholars who support the notion of self-ownership draw support for their arguments from Lockean labour theory, a theory that is premised upon self-ownership. James Harris, a critic of the notion of self-ownership, argued that that Lockean theory' s reliance on self-ownership meant that is was premised upon one of the greatest non-sequitors' in legal history: J Harris, Property and Justice XX.
} 
for this, as we have seen, is a low one: the material must have a physical existence and be separate from the potential right holder. If these are satisfied then the answer to the first question is 'yes'.

\section{B. Should human biomaterials form the subject matter of a property right?}

As a matter of principle, separate human biomaterials can form the subject matter of a property right. Whether they should form the subject matter of a property right, however, is a matter of policy. As McFarlane notes, in some cases ' ... the particular nature of a physical object may make the idea of having a right to that object, prima facie binding on the whole world, distasteful, inappropriate or otherwise unwelcome. ${ }^{48}$ Many have argued that human biomaterials fall into this category, and the approach of the courts in England and Wales until recently would seem to reflect this view. ${ }^{49}$ Such policy underpinned to some degree the judicial reluctance to simply apply the rules of property law to bodies and their parts just as they might be applied to any other physical item. Similarly, those who find it inappropriate to permit ownership of human bodily tissue have advocated alternative forms of regulation. ${ }^{50}$ We here explain what the recognition of property rights in human biomaterials would entail at a doctrinal level. It is then for courts and commentators to decide whether or not this would be desirable.

Let us return to our core. As we saw above, if we were to say that A holds a property right in respect of the tissue sample, this would mean that all other persons (B, C, D etc), owe A a duty to refrain from physical interferences with the tissue sample. This is the principle consequence of a finding that one can hold a property right in respect of human biomaterials. The question for a court is whether or not it is appropriate to establish such duties in relation to human biomaterials: should persons

\footnotetext{
${ }^{48}$ McFarlane, Structure of Property Law, 137.

${ }^{49}$ For centuries, the position was that a corpse was not an appropriate subject for ownership due to its special nature and associated religious reasons: P. Matthews, 'Whose Body: People as Property’ 36 Current Legal Problems 193.

${ }^{50}$ For example, at one point Loane Skene argued in favour of source individuals having a 'personal autonomy right' not to have body parts removed: Skene, 'Proprietary Rights in Human Bodies, Body Parts and Tissue', 123. Jonathan Herring supports a regulatory scheme: \{Herring, 2014 \#587\}. See also those who have made various suggestions based on a personality or personal injury, rather than property, basis: N. Whitty, 'Rights of Personality, Property Rights and the Human Body in Scots Law' EdinLR Vol 9 pp 194-237; Shawn H. E. Harmon, 'Yearworth v. North Bristol NHS trust: a property case of uncertain significance?’ (2010) Med Health Care and Philos 13:343-350, 348-349.
} 
generally be under a duty to refrain from interfering with a blood sample, excised cells or a donated organ?

Some have argued that it would be deeply inappropriate to recognise these exclusionary duties in respect of human biomaterials. ${ }^{51}$ This primarily stems from the importance that such materials have in the field of medical research. Moore $v$ Regents of University of California is a striking example of this. The cells excised from the claimant were used to develop a cell line that was incredibly valuable in developing new treatments for medical conditions. Given the public importance of such assets, is it appropriate to leave such things to a set of rules which permit owners to exclude all others? When the Japanese businessman, Ryoei Saito, announced his intention to have his Van Gogh and Renoir paintings placed in his coffin and cremated with him, there was international outrage. In terms of property law, however, there was little others could do: their duty was to refrain from interfering with Saito’s paintings, meaning that they could not, as a matter of law, exercise control over them. ${ }^{52}$ Do we wish to throw human biomaterials to a set of rules which can facilitate the capriciousness of the private owner?

This may be a powerful reason not to recognise property rights, and indeed the case law supports this as we can arguably see the problematic implications of permitting individuals to be driven by their own desires in relation to their tissue. The United States decision in Colavito $v$ New York Organ Donor Network (2006-07). ${ }^{53}$ Robert Colavito was suffering from end stage renal disease and needed a donor kidney. Upon the death of his friend, Peter Lucia, Lucia's wife attempted to donate both of her husband's kidneys directly to Colavito by indicating this on the consent to donation form. The form included a term that permitted the organs to go to someone else if they could not be used by the donee. ${ }^{54}$ After the kidneys were removed, one kidney was sent to Colavito's transplant team but it turned out to be unusable due to the presence of an aneurysm. Meanwhile, the other kidney was transferred elsewhere

\footnotetext{
${ }^{51}$ See, for example, the views of Herring, Murray and Skene noted earlier.

${ }^{52}$ A limited form of protection against such an act may come from intellectual property law which affords moral rights to the author of such a work to prevent its destruction in certain circumstances. However, this protection is personal to the author and could not be invoked by others.

${ }^{53}$ Colavito v New York Organ Donor Network (Nos 1-4) 356 F Supp 2d 237 (E.D.N.Y., 2005); 438 F.3d 214 (USCn Cir., 2006); 8 N.Y.3d 43 (CA N.Y., 2006); 486 F.3d 7878 (U.S. C.A. 2nd Cir., 2007). ${ }^{54}$ Colavito v New York Organ Donor Network (No. 1) 356 F Supp 2d 237 (E.D.N.Y., 2005), 238-9.
} 
and successfully transplanted. It later emerged later that neither kidney was a compatible match for Colavito. Colavito claimed in conversion against the New York Organ Donor Network, arguing that when Mrs Lucia made the directed donation, the kidneys became his property and in directing one of them to another recipient, the defendants had interfered with his right to possess them. Colavito wanted access to both kidneys and was upset that this had been denied to him.

Colavito's claim failed. Had it not, and the court recognised Colavito as having property rights in both organs, then he would have been able to exclude others from organs that were useless to him. A successful claim would have led to one of those kidneys going unused, wasting a potentially life-saving donor organ. In this kind of situation, Herring's views about regarding tissue as a community resource and the undermining effects of property would have some bite.

However, there are three points that should be considered before a court decides to eschew a property approach. The first is that the exclusionary duties that come with property rights are not necessarily inconsistent with the promotion of a public use of certain goods. Take the example of the National Gallery in London, which is a charitable trust. All of the paintings held in the gallery are the subject of standard private property rights, and most of these rights are vested in the charitable trustees. The existence of these rights plays an important function as it means that a member of the public cannot lift a painting off the wall and take it away with impunity; they would be breaching a duty of non-interference owed to the trustees. The existence of this legal duty, therefore, gives the trustees the security of peaceful possession of the paintings which actually allows the trustees to display the paintings to the public. ${ }^{55}$ One way to avoid the capriciousness of Saito is by ensuring that property rights in such items vest in the right owner, such as the National Gallery, rather than denying property rights at all. The obvious candidate in the context of human biomaterials is that of biobanks. Because these institutions can have charitable functions, allocating property rights in human biomaterials to them may actually facilitate uses of such materials that are for the 'public good'.

\footnotetext{
${ }^{55}$ Such security cannot be achieved merely by reference to a law against theft, as theft is necessarily premised on a system of private property and the right to exclusive possession that that allows.
} 
The second point that a court should bear in mind before rejecting a property approach is that it could create something of a legal void. When a thing, such as a coin, painting or cell line, has some value, then it is inevitable that more than one person will want to possess and make some use of it. We often refer to this as the condition of 'scarcity', which creates a state of affairs where one person, wishing to make use of the scarce material, will find it profitable to predate on and dispossess another person who is possessing the material. ${ }^{56}$

Property rights are an excellent antidote to this risk of dispossession. If a certain chattel or plot of land is subject to a property right, then all persons come under a duty precisely to refrain from attempting to dispossess the right holder. ${ }^{57}$ However, if these duties are removed, meaning that predation and dispossession can occur with impunity, then rule of law and public order issues arise. If a court were to hold that a valuable cell line, or a blood sample with particular scientific interest, could not be the subject of a property right, then how would the legal system react if peaceful possession of such items were disturbed?

Traditionally it has turned to the law of theft, which ought necessarily to raise the question of property status of that tissue. ${ }^{58}$ Yet this does not avoid the difficulties described in the last paragraph. Take the case of $R v$ Kelly where the defendants were charged with theft for taking dissected specimens from a museum. The difficulty is that theft is defined as taking property belonging to another ${ }^{59}$ and, as such, it presupposes that the stolen thing is the subject of another's property right. The court recognised this and, consequently, felt it necessary to ask whether the specimens were in fact the subject matter of property rights. ${ }^{60}$

The third point that should be born in mind is that the existence of property rights is not necessarily inconsistent with other systems of regulation that have been

\footnotetext{
${ }^{56}$ See, eg, the famous passage in D Hume, A Treatise of Human Nature, Book III, Part 1, Sect 2.

${ }^{57}$ These duties are not enforced directly through the action of a vindicatio, but find their expression throught the 'oblique' or 'indirect' claim in the tort of conversion. See P Birks, 'Personal Property: Proprietary Rights and Remedies’ (2000) 11 KCLJ 1.

${ }^{58}$ See $R v$ Rothery (1976) Crim LR 691; $R$ v Herbert (1961) 25 J CR L 163; $R v$ Farrant Crim LR; $R v$ Welsh (1974) RTR 478. See also the discussion in Roche $v$ Douglas as Administrator of the Estate of Edward Rowan (dec'd) (2000) WASC 146.

${ }^{59}$ Ss 4, 5 Theft Act 1968.

${ }^{60}$ Applying the Doodeward exception, it was held that they were and the defendants were convicted for theft.
} 
proposed in respect of human biomaterials. The Nuffield Council on Bioethics, in their influential report on the regulation of human tissue, debated whether such material should be regulated by property rights, or on a system based upon consent. The 'consent model' is based upon the idea that research institutions would only be permitted to carry out research on human tissue samples that was consented to by the source of the material. This consent model was preferred to the property model by the Council, and this approach was the one favoured in the Human Tissue Act 2004. However, there is nothing within the law of property that is inconsistent with a consent based approach. Take another analogy from the National Gallery. A donor may be willing to make a gift to the gallery of a painting, but only on certain conditions, such as that the painting is never loaned out and is displayed in a special gallery. ${ }^{61}$ However, whilst the terms by which the donor consented to the gift should obviously restrict how the National Gallery uses the painting, ${ }^{62}$ this does not displace the role of property law: there is still a need to ensure that a member of public is not able to take the painting off the wall in the special gallery with legal impunity. The law of property is good at doing this, by imposing general duties of non-interference on all others. So whilst property rights in human biomaterials are not being advocated here, it is important to point out that there is nothing within the law of property that is inconsistent with an approach that respects the consent of donors of human biomaterials. Indeed, property devices such as bailment would have resolved the situation in some of the cases considered here, and were in fact used in Yearworth precisely to do so. What this suggests is that there are tools and devices in the law of property that can assist in achieving many of the outcomes that seem ethically sound.

\section{Who has acquired the right?}

If a court answers the preceding question in the affirmative, the question that logically follows is: to whom would the property right be allocated? As we saw above, courts have sometimes ignored this question, and have not have not attempted to apply the rules and doctrines that govern the acquisition of property rights to human

\footnotetext{
${ }^{61}$ For example, the Frick Gallery in New York is subject to severe limitations that block the sale of existing paintings and indeed whether those paintings can travel outside the gallery: E.L. Glaeser, 'Introduction' in E.L. Glaeser (ed), The Governance of Not-for-Profit Organizations (University of Chicago Press, 2003), 28

${ }^{62}$ Note that there are comprehensive rules governing this, related primarily to the variation of trusts.
} 
biomaterials. Yet this should be a crucial stage of the litigation. Take our core case again, where $\mathrm{A}$ asserts that $\mathrm{B}$, by making some unauthorised use of a tissue sample, has infringed A's property right. The issue of allocation will have a decisive impact upon the claim. If the court, after recognising that the tissue sample can form the subject matter of a property right, decides that the right should vest in $A$, then this provides a basis for A's claim. Conversely, should the court hold that the right should be allocated to B, then A's claim must fail, as A cannot plead that B has infringed 'A's right'. The importance of the allocation issue goes beyond deciding the outcome in litigation. As we have seen, to recognise a property right in respect of human biomaterials has the effect of imposing a legal duty on all persons to refrain from interfering with the material. As a simple point of natural justice, it is imperative that those burdened by the duty are able to discover to whom they owe the duty: A or B, or some third person, $\mathrm{X}{ }^{63}$ For these reasons the issue of allocation is of central importance in these types of claims.

The law of property has developed a number of rules governing the acquisition of property rights. It is these rules that the court should turn to in order to determine the allocation issue. It will be helpful to give a brief overview of these rules as this will demonstrate the different options open to an adjudicator. These rules can broadly be divided into those governing the initial acquisition of property rights, and those governing the subsequent, or derivative, acquisition of property rights.

\section{Initial acquisition}

In our core case, the tissue becomes a new thing in the sense that it did not previously exist independently of A. As a new thing, not subject to any pre-existing property rights, the court must decide in whom the property right will initially vest. The default rule, as explained above, is that a property right will initially be acquired by the person who first takes possession of it. By way of illustration, consider the famous case of Pierson $v$ Post ${ }^{64}$ where the claimant was chasing a fox with his hounds and, just before catching it, the defendant shot it and took it away. The fox, like the tissue sample in our core case, was res nullius, not being the subject of any pre-existing

\footnotetext{
${ }^{63}$ Note Young v Hitchens (1844) 6 QB 606, 115 ER 228.

${ }^{64}$ (1805) 3 Cai R 175. For English cases see Churward v Studdy (1811) 14 East 249, 104 ER 596 and Young v Hitchens (1844) 6 QB 606, 115 ER 228.
} 
property rights, so the court had to decide in whom the right would initially vest. Applying the default rule, because the defendant had taken possession of the fox before the claimant could, the law allocated a property right to the defendant. If this rule were applied to our core case, then it would likely favour B, as it is probably B, in excising the tissue from $\mathrm{A}$, who is the first to take possession.

The operation of the default rule has the benefit of certainty, as determining who was the first to possess a thing is usually a straightforward factual question. ${ }^{65}$ However, the rule may be criticised for being arbitrary, as first possession is often purely random and accidental. In Pierson, for instance, the defendant was clearly opportunistic, whilst the claimant's efforts in chasing and tiring the fox went unrewarded. A court adjudicating a dispute over human biomaterials may not wish to leave the issue of allocation to such chance. One option, if the court's sympathies lay in this direction (as they have in the past ${ }^{66}$ ), would be to apply a rule that always allocated the right to $\mathrm{B}$. The argument here would be that it is B who, by her skill and effort, has been able to create the new thing, the tissue sample. An analogy may be found in the legal principle called the specificatio. This is a Roman law principle, that has been adopted in the common law, ${ }^{67}$ that is applicable in cases where a person has transformed one thing, such as grapes or bronze, into another thing, such wine or a statute. Whilst the legal response to this type of scenario changed over time in Roman law, one solution was to vest title in the new thing in the person who spent time and effort in creating it. This principle may not apply directly to all cases involving human biomaterials. Although a surgeon who has taken a blood or tissue sample may be said to have created a new thing - in the sense that the blood or tissue did not previously exist as an independent thing - it is usually more difficult to say that the blood or tissue has been transformed from one thing to another. Yet specificatio, and its apparent purpose of rewarding skill and effort, would be a helpful analogy for any court seeking to displace the default possession rule with a rule it considers more appropriate in the circumstances.

\footnotetext{
${ }^{65}$ Although compare Young v Hitchens (1844) 6 QB 606, 115 ER 228.

${ }^{66}$ See the Doodeward, Kelly line of cases.

${ }^{67}$ Clough Mill Ltd v Martin [1985] 1 WLR 111.
} 
Should the court's sympathies lie elsewhere, and it considers that a more appropriate outcome would be that a property right should always be allocated to the source of the material, it would always be open for a court (of sufficient seniority) to develop a sui generis rule for such scenarios. Several normative arguments have been made in favour of allocating property rights to the source of the material, most based upon notions of personhood or a desire to reflect the sources interests in the tissue, such as privacy. These could find legal expression in a rule which provides that when tissue, or any other material, is excised or ejected from A's person, title to the material immediately vests in A, regardless of who is the first to possess the material. Such sui generis rules are not uncommon in the law, and this option would certainly be open to the court in our core case.

A third alternative to the default possession rule would be to allocate a property right to a third party. In our core case, it would be possible for a court to decide that although the tissue sample can be made the subject of a property right, the right should be allocated to neither to A nor B, but some third party, X. It may be that the court considers some other party, such as the state or a biobank, to be the most appropriate owner of the material, particularly if the court is concerned that the material be used for some public good. Whilst this would be the most radical solution to the problem, there are clear analogies for such an approach. One is the rule governing the position of a person who finds a chattel that is legally classed as treasure. In such cases title to the material does not vest in the finder, but in the state. ${ }^{68}$ This is despite the fact that the state does not have any historical involvement either in the secreting of the treasure, or in the finding of it. The allocation rule is based simply on the view that the state is the most appropriate owner of such material. A similar position could be taken in respect of human biomaterials.

These are the obvious options open to a court adjudicating a dispute over human biomaterials. Powerful normative arguments have been made for each choice, and whichever one a court settles upon will not satisfy everyone. However, once a court has decided that human biomaterials should be made the subject matter of a property right, the most important thing is that the court clearly allocates that right to

${ }^{68}$ [Treasure Act] 
someone. Otherwise, it will not be clear whom the duty of non-interference is owed to: A or B or X? This is a situation which the law cannot tolerate. As such, it is more important that a court make an allocation of rights, than it is that those rights be allocated to the 'best' person. In other words, an element of arbitrariness when it comes to allocation can be tolerated, so long as the law is clear. In this sense, the first possession rule may have much to commend itself to the court.

\section{Subsequent acquisition}

A normal incident of property rights is the power to transfer. There are few examples of property rights that are not capable of being transferred from one person to another. ${ }^{69}$ The starting point, it would seem, is that property rights in respect of human biomaterials would operate in the same way. If a court adjudicating our core case were to decide that rights in the tissue initially vested in A, then there seems to be no reason why A could not subsequently transfer that right to another. ${ }^{70}$ Property rights can be transferred in a number of ways, depending upon the nature of the physical thing. A common method is by a physical transfer of possession (usually called a 'delivery ${ }^{, 71}$ ). If A consents to the transfer of property rights in the tissue to $\mathrm{B}$, for example, then it could be said that there is a 'delivery' in our core case, as A allows $\mathrm{B}$ to take possession of the tissue following its excision.

One implication of the power to transfer is that it provides a means by which a person in the position of $\mathrm{B}$ could ensure that his activity is lawful. It would be possible for $\mathrm{B}$ to make it a condition of treating A that any title to excised tissue be transferred to B. So whilst title could initially vest in A (depending on which acquisition rule is adopted by the court), B could argue that he subsequently acquired the title as a result of a transfer, thus making any research he does on the material lawful.

\footnotetext{
${ }^{69}$ A non-assignable lease may be an example; historically there were restrictions on transferring title to land.

70 This could be via gift, sale or transfer of limited rights via bailment.

${ }^{71}$ Note that there are other ways to achieve this: by deed and contract of sale; in regards to land, by grant and registration.
} 
Property law has well established and clear rules of disposing rights. They provide certain methods of transfer ${ }^{72}$ and clear guidance on the consequences of failing to comply with these requirements. The legal uncertainty currently surrounding the issue of ownership of body parts could be avoided to an extent if the existing body of law on transfer were applied to human tissue in the same way as it is applied to any other chattel. These rules of transfer can provide answers to questions such as: has there been a permanent and full transfer, a transfer on trust or a mere bailment? Such initial clarity and the application of established means of determining these questions would avoid the kind of problems that arose in Catalona, Yearworth and Colavito.

Two points must be made about the possibility of transfer. The first is that the question of whether a right has been transferred is logically subsequent to the question of whom the right initially vests in. It will be recalled that one criticism made of the case of Catalona was that the court invoked the notion of 'transfer' before determining whether the putative transferor had any property rights that were capable of being transferred. In our core case, it would only make sense for B to argue that A had transferred a property right in the tissue sample if the court had first determined that the right initially vested in A; otherwise there would be no right capable of being transferred.

The second point that must be made that must be made is that whilst transfer is a typical incident of property rights, it is often subject to legal regulation. For instance, the owner of a painting by Turner may find that he has committed a crime by selling the painting to an overseas buyer without first getting the consent of the state. ${ }^{73}$ A more mundane example is that of a car owner who must inform the relevant authorities of any changes in ownership. These forms of public control are not seen as being inconsistent with property rights, but are actually quite a common feature. It may be that a similar scheme of regulation is seen as appropriate when it comes to the transfer of property rights in human biomaterials.

\footnotetext{
${ }^{72}$ Specifically deed, delivery and sale. See Cochrane v Moore (1890) 25 QBD 57.

${ }^{73}$ Under the Export Control Act 2002, s. 1(1) the secretary of state is able to make orders restricting the export of certain goods including cultural objects such as paintings.
} 


\section{Would there be any defences to the property right?}

Let us say that in respect of our core case, that a court has held that the tissue sample can and should form the subject matter of a property right, and that that right vests in the source, A. Let us further say that A has not transferred this right to B. The legal consequences of such a finding would be that $\mathrm{B}$, along with all other persons, would owe A a duty of non-interference with the tissue sample. If it appears that B has conducted some research on the tissue sample (as happened in Moore), then, prima facie, it would appear that B would have committed a legal wrong. At this stage in the litigation, the relevant question that the court will need to ask is whether B would have any defences to A's claim? It is never the case that property rights are 'absolute', in the sense of imposing strict liability upon all persons in all circumstances. The common law has always recognised that there are reasons why B's conduct may be excusable by the recognition of a defence. ${ }^{74}$

The most obvious defence that B can invoke is that of consent. This would be an easy way for B to protect himself and his research activities from any claims by A. B could insist that A waive his rights as a condition for undergoing the procedure. Whilst A may have title to the material, therefore, B would not be committing a legal wrong by conducting research on it.

A second possibility for B is to argue that the property right held by $\mathrm{A}$ in respect of the tissue has been destroyed due to the operation of a property law doctrine. An example would be the doctrine of abandonment. Although there is controversy as to whether a doctrine exists, it is the case that the law will permit the doctrine to operate in limited factual contexts. ${ }^{75}$ It may be that human biomaterials present another context in which courts would feel it appropriate for the doctrine of abandonment to operate. If so, then it may be possible for B to argue that although property rights in the tissue vested in A, A abandoned those rights by permitting the excision of the material. The difficulty with this argument is that it would require

\footnotetext{
${ }^{74}$ We use the word 'defence' in a very wide sense, to describe any argument that B could make in order to avoid liability.

${ }^{75}$ Particularly in the context of the law of wreck and salvage of ships: The Crystal [1894] AC 508 and A Hudson, 'Abandonment' in N Palmer and E McKendrick (eds), Interests in Goods (2nd ed, LLP, London 1998).
} 
clear evidence of a divesting intention on A's part. This could be met, most likely, if A were to sign a form expressing his intention to 'abandon' before undergoing the operation. It is important to recall, however, that the abandonment argument will only ever be relevant if there is a property right to abandon. In other words, it would only make sense for B to plead this defence if the court allocated a property right to A in the first place. Without this qualification, one will encounter the problems discussed in relation to the Nuffield Council's report.

A third defence would be a simple bona fide defence that the law could develop. There are a number of contexts, often involving money, where the strictures of property law are moderated, and a defendant will escape liability if he can show good faith. ${ }^{76}$ Given the interest in scientific research, and the importance of human biomaterials to this activity, there may be good policy reasons to develop such a defence for research institutions acting in good faith.

\section{CONCLUSION}

In this paper we have identified a number of key misconceptions that have dogged the judicial and academic consideration of whether human tissue should be dealt with as personal property. We have avoided taking an overt stance on which approach to the regulation of human tissue is to be preferred, but we would say that a property-based approach would facilitate many of the outcomes advocated by those who currently debate how we should deal with tissue. For those seeking increased individual control, adopting a rule of acquisition that affords the source individual initial ownership of excised tissue could achieve this. Alternatively, a community-ownership model could be achieved via trust devices or restrictions on individual control. It may well be that we need to adapt some aspects of the property system for it to work in the manner desired in relation to tissue, and there may be lessons to be drawn on in this regard from the development of the intellectual property system. These, however, are policy decisions about the outcomes we want to achieve in relation to tissue, and should remain separate from decisions about which legal device best achieves them. If

\footnotetext{
${ }^{76}$ Banknotes and cheques are two examples where a bona fide purchaser defence applies. See Miller $v$ Race (1758) 1 Burr 452 and Cheques Act 1957, s. 1(1).
} 
we are to accurately evaluate the law of property is the right device, we should first consider these policy questions and the ethical issues that attend them, and then determine which legal device will best lead to these outcomes. When we come to this second question, if property is that device, then we should be mindful of being accurate in our reference to the laws of property. We hope that the methodology we offer here will facilitate such accuracy in consideration by future courts who are asked to adjudicate on how human tissue and parts may be treated. 